\title{
Comparative duodenal, jejunal and ileal responses to luminal saline load
}

\author{
AR Chikh-Issa ${ }^{1, *}$, G Charpin ${ }^{1,}$ C Dumas ${ }^{1}, \mathrm{P}$ Nicol ${ }^{1}$, \\ D Pansu 2, M Descroix-Vagne ${ }^{1, * *}$
}

\author{
1 Hôpital Edouard Herriot, INSERM Unité 45, pavillon H bis, Lyon; \\ 2 Hôpital Edouard Herriot, École Pratique des Hautes Études, 69437 Lyon Cedex 03, France
}

(Received 14 October 1991; accepted 16 February 1993)

\begin{abstract}
Summary - Intestinal ionic exchanges were studied in rat duodenal, jejunal and ileal ligated loops in response to different luminal saline loads: $\mathrm{NaCl}$ concentration varied from $150-0 \mathrm{mM}$, solutions being made isoosmotic with mannitol. The contact delay was $60 \mathrm{~min}$. An exponential relationship was found between water, $\mathrm{Na}$ and $\mathrm{Cl}$ movements and the initial saline concentration. Maximal absorption was obtained with $150 \mathrm{mM} \mathrm{NaCl}$, and was significantly higher in the duodenum than in the jejunum and ileum. The $\mathrm{NaCl}$ concentration for which water, $\mathrm{Na}$, and $\mathrm{Cl}$ movements were null was = $70 \mathrm{mM} \mathrm{NaCl}$ in the duodenum and jejunum, $41 \mathrm{mM}$ for $\mathrm{Na}$ and $18 \mathrm{mM}$ for $\mathrm{Cl}$ in the ileum. The water efflux induced by the $0-\mathrm{mM} \mathrm{NaCl}$ test solution was maximal in the duodenum $(1.5 \pm 0.2 \mathrm{ml} / \mathrm{h})$ and decreased in the jejunum $(0.8 \pm 0.1 \mathrm{ml} / \mathrm{h})$ and ileum $(0.3 \pm 0.1 \mathrm{ml} / \mathrm{h})$ as did sodium, chloride and nonchloride anion efflux. These data support the functional heterogeneity of the small intestine regulating the water and ion exchange in response to luminal saline load, the main difference being connected with the efflux capacity of the mucosa, decreasing from the duodenum to the jejunum and ileum.
\end{abstract}

absorption / secretion / rat / sodium / chloride / small intestine

Résumé - Réponses comparées du duodénum, du jéjunum et de l'iléon à une charge saline intraluminale. Les échanges ioniques en fonction de la concentration de $\mathrm{NaCl}$ de la solution test ont été étudiés au niveau du duodénum, du jéjunum et de liléon du rat par la méthode des anses ligaturées in situ. Les concentrations de $\mathrm{NaCl}$ ont varié de $150 \mathrm{mmol}^{-1}$ à $0 \mathrm{mmol}^{-1}$, lisosmolarité était assurée par la mannitol, le temps de contact était de $60 \mathrm{~min}$. Une relation exponentielle a été mise en évidence entre les mouvements de l'eau, de sodium et de chlore et la concentration saline initiale intraluminale. L'absorption maximale, observée avec la solution contenant $150 \mathrm{mmol} . \mathrm{t}^{-1}$ de $\mathrm{NaCl}$, était significativement plus élevée dans le duodénum que dans le jéjunum et liléon. L'absorption nulle a été observée pour une concentration luminale de $70 \mathrm{mM}$ dans le duodénum et le jéjunum, de $41 \mathrm{mM}$ pour $\mathrm{Na}$ et de $18 \mathrm{mM}$ pour le $\mathrm{Cl}$ dans l'iléon. L'efflux d'eau en l'absence de $\mathrm{NaCl}$ dans la lumière a diminué du duodénum $(1,5 \pm 0,2 \mathrm{~m} / \mathrm{h})$ au jéjunum $(0,8 \pm 0,1 \mathrm{~m} / \mathrm{h})$ et à liléon $(0,3 \pm$ $0,1 \mathrm{~m} / \mathrm{h}$ ), l'efflux de sodium, de chlore et de bicarbonate a diminué significativement dans le sens

\footnotetext{
* Present address: Faculté de Médecine, Damascus, Syria

** Correspondence and reprints
} 
aboral. Ces résultats confirment la réponse différenciée des 3 segments de l'intestin grêle en réponse aux variations de la concentration saline luminale, la différence paraissant liée d'une part à la diminution de la perméabilité tissulaire, d'autre part à la capacité de réponse sécrétoire du duodénum.

absorption / sécrétion / rat / sodium / chlore / intestin grêle

\section{INTRODUCTION}

The ionic exchange across the intestinal barrier depends on the luminal electrolyte concentration (Field, 1981; Armstrong, 1987; Powell, 1987). Since pilot studies in which several isoosmotic non-ionic solutions were tested (Hindle and Code, 1962; Fordtran et al, 1965), saline solutions made isoionic with the extracellular liquid, like Ringer or Tyrode solution, have been used to explore the absorption or secretion induced by hormones or neutransmitters. For several years we have been using the in vivo ligated loop to determine water and ion fluxes in response to gastrointestinal hormones. The controls were placed in an equilibrium with a null water flux by using low $\mathrm{NaCl}$ concentration test solutions made iso-osmolar by mannitol. Under these conditions, it was possible to compare the secretion induced by vasoactive intestinal peptide (VIP) at 3 levels of the small intestine, ie the duodenum, jejunum and ileum (Chick-lssa et al, 1992). An increase of duodenal absorption by [D Ala, Met] enkephalinamide (DAMA), angiotensin II and sorbin peptides was demonstrated (Charpin et al, 1992). Sorbin is an intestinal peptide isolated from porcine intestine (Vagne-Descroix et al, 1991) whose C-terminal peptides are the active site of 153 residue sorbin. Maximal effective dose of sorbin peptides decreased $\mathrm{Na}$ and $\mathrm{Cl}$ concentration to 75 and $40 \mathrm{mM}$ respectively, a decrease of the same magnitude as that induced by DAMA. For all sorbin peptides, dose-response curves showed a supramaximal inhibition, sug- gesting that the duodenum could not maintain a lower luminal concentration. This study was undertaken to explore the relationship between $\mathrm{Na}$ and $\mathrm{Cl}$ luminal concentration and fluxes across the mucosa and to compare them at 3 levels of the small intestine.

\section{MATERIALS AND METHODS}

\section{Animals}

Male Sprague-Dawley rats $\approx 180$ rats, Iffa Credo, F 69210 L'Arbresle), $200 \pm 5 \mathrm{~g}$, were fasted for $48 \mathrm{~h}$ with free access to water. They were anesthetized with intra-peritoneal pentobarbital $(4.2 \mathrm{mg} / 100 \mathrm{~g} \mathrm{BW})$, laparotomized, and $10-\mathrm{cm}$ long loops constituted. The duodenal loop began at the pylorus and was delimited by 2 cotton sutures (00); the hepato-biliary canal was tied off. The jejunal loop began just after the duodenal loop. The ileal loop began at the ileo-caecal valve and $10 \mathrm{~cm}$ upstream. After rinsing the luminal segment with the test solution, $1 \mathrm{ml}$ of test solution was instilled into each loop with the aid of a calibrated syringe and an additional ligature was placed at each of the injection sites. The ligated loops were replaced in the abdominal cavity which was then sutured. The animals were kept in an incubator at $25^{\circ} \mathrm{C}$ and reanesthetized if necessary. Sixty min later, they were killed by an intravenous injection of air; the loops were exteriorized, cut just proximally to the outside of the ligatures and the contents of the squeezed loops were collected, centrifuged and the volume of the supernatant measured.

The test solutions which were instilled into the loops contained $0-150 \mathrm{mM} \mathrm{NaCl}$ (respectively $0,25,50,75,100,125,150 \mathrm{mM} \mathrm{NaCl}$ ). 
The osmolarity was maintained by adding complementary amounts of mannitol (respectively $300,250,200,150,100,50,0 \mathrm{mM}$ mannitol). Recovery of the intestinal contents was controlled by adding $0.05 \mu \mathrm{Ci} / \mathrm{ml}$ tritiated polyethylene glycol 4000, [3H]-PEG 4000 as nonabsorbable marker (NEN, D-6072, Dreieich 4, Germany), mixed with $5 \mathrm{~g} / 1$ cold PEG 4000 . Only those loops where recovery of $\left[{ }^{3} \mathrm{H}\right]-\mathrm{PEG}$ 4000 was $>85 \%$ were analyzed. Recovery of $\left[{ }^{14} \mathrm{C}\right]-$ mannitol in the final contents was determined in a complementary study using 3 concentrations $(0,75,125 \mathrm{mM} \mathrm{NaCl}$ and 300,150 , $50 \mathrm{mM}$ mannitol).

$\mathrm{Na}$ and $\mathrm{K}$ contents were measured by flame photometry, $\mathrm{Cl}$ by coulometric titration, bicarbonate by alcali-acid titration. The $\mathrm{pH}$ was checked before (6.9) and after the 60-min incubation period (Radiometer Copenhagen, Denmark). Radioactivity was determined by liquid scintillimetry, with a double counting program (Tri-Carb 1600 , Packard, Paris). All data are given per $10 \mathrm{~cm}$ loop as the mean of at least 6 rats \pm the standard error of the mean (SEM). Osmolarity was calculated from cations and mannitol concentration using the conversion tables (Weast, 19861987).

The means were compared by variance analysis. Curve-fitting via exponential equation after change of variable was computerized with Graphpad (ISISoftware from H Motulsky, Department of Pharmacology, University of California, San Diego, CA). Goodness of fit was quantitated by the least-squares method.

\section{Animal management}

Animal management followed the directives of the European Economic Community (Journal des Communautés Européennes No $L 358$, 18.12.1986 1-28) (Registered user No 191).

\section{RESULTS}

For each concentration tested the macroscopic aspect of the loop remained normal and without hemorrhage even when low ionic solutions induced an increase of the luminal volume.

\section{Water movement}

Figure 1 shows the individual values, means and nonlinear relationship obtained between the final water contents of the loop and the initial $\mathrm{NaCl}$ concentration in the test solution. The maximal water absorption (negative values, corresponding to a mucosa to serosa transport) was obtained for the $150 \mathrm{mM} \mathrm{NaCl}$ solution for duodenum $(-0.87 \pm 0.05 \mathrm{ml} / \mathrm{h})$, jejunum $(-0.57 \pm 0.4 \mathrm{ml} / \mathrm{h})$ and for $125 \mathrm{mM} \mathrm{NaCl}$ for ileum $(-0.54 \pm 0.08 \mathrm{ml} / \mathrm{h})$. Water absorption was statistically higher in the duodenum $\left({ }_{26}^{2} F=14.48, p<0.001\right)$. Water absorption decreased with the decrease in luminal $\mathrm{NaCl}$ concentration. The null values were observed for $70 \mathrm{mM} \mathrm{NaCl}$ in the duodenum, $60 \mathrm{mM}$ in the jejunum and $18 \mathrm{mM}$ in the ileum. Lower concentrations induced a positive water movement, corresponding to a passage from the serosa to the mucosa which was maximum for $0 \mathrm{mM}$ $\mathrm{NaCl}$. The maximal secretion obtained varied widely with the intestinal segment from $1.54 \pm 0.20 \mathrm{ml} / \mathrm{h}$ in the duodenum, $0.84 \pm$ $0.10 \mathrm{ml} / \mathrm{h}$ in the jejunum to $0.27 \pm 0.02 \mathrm{ml} /$ $\mathrm{h}$ in the ileum $\left({ }_{14} F=26.8, p<0.001\right)$.

\section{Na movement}

Figure 2 shows the individual values, the means and the non-linear relationship between $\mathrm{Na}$ flux and the initial $\mathrm{Na} \mathrm{Cl}$ concentration of the test solution. The maximal absorption was obtained for $150 \mathrm{mM} \mathrm{NaCl}$, calculated from the curve in the duodenum because of the lack of volume remaining; the values were $-99 \mu \mathrm{Eq} / \mathrm{h}$ in the duodenum, $-93 \pm 5 \mu \mathrm{Eq} / \mathrm{h}$ in the jejunum and $-71 \pm 9 \mu \mathrm{Eq} / \mathrm{h}$ in the ileum.

A decrease in absorption was induced by the decrease in luminal $\mathrm{NaCl}$ concentration. The null value was observed for $78 \mathrm{mM}$ $\mathrm{NaCl}$ in the duodenum, $70 \mathrm{mM}$ in the jeju- 

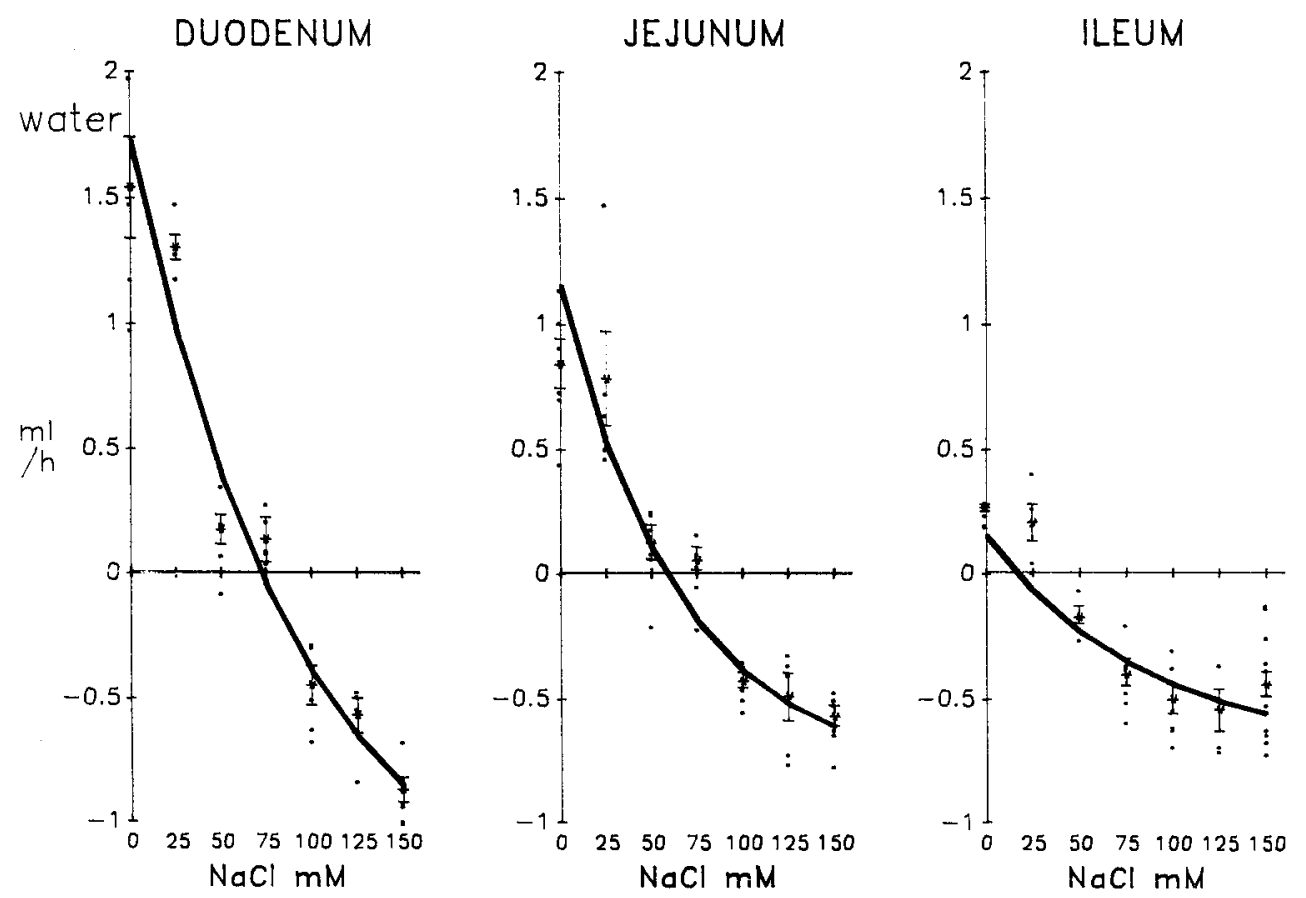

Fig 1. Net water flux in the duodenum (left) (39 rats), jejunum (middle) (43 rats) and ileum (right) (49 rats), according to the initial $\mathrm{NaCl}$ concentration of the test solution. Addition of mannitol provided isoosmolarity $(300 \mathrm{mOsm} / \mathrm{kg})$ in the test solution. Stars indicate the means and vertical bars the SEM. The line represents the exponential curve calculated after change of the dependent variable and computerized with Graphpad (ISISoftware; H Motulsky, Dept of Pharmacology, University of California, San Diego, USA). Goodness of fit was quantitated by the least-squares method. Positive values correspond to secretion and negative values to absorption.

num and $41 \mathrm{mM}$ in the ileum. Secretion was then induced with lower luminal $\mathrm{NaCl}$ concentration under these values, the maximal secretion with no $\mathrm{NaCl}$ being $259 \pm 29$ $\mu \mathrm{Eq} / \mathrm{h}$ in the duodenum, $133 \pm 17 \mu \mathrm{Eq} / \mathrm{h}$ in the jejunum and $42 \pm 3 \mu \mathrm{Eq} / \mathrm{h}$ in the ileum $\left({ }_{14} F=34.8, p<0.001\right)$.

\section{Cl movement}

Figure 3 shows the individual values, means and nonlinear relationship between net $\mathrm{Cl}$ flux and the luminal initial $\mathrm{NaCl}$ concentration. Maximal $\mathrm{Cl}$ absorption was obtained with $150 \mathrm{mM} \mathrm{NaCl},-111 \mu \mathrm{Eq} / \mathrm{h}$ in the duodenum (calculated), $-93 \pm 6 \mu \mathrm{Eq} / \mathrm{h}$ in the jejunum and $-112 \pm 4 \mu \mathrm{Eq} / \mathrm{h}$ in the ileum. A null $\mathrm{Cl}$ movement was observed for $62 \mathrm{mM} \mathrm{NaCl}$ in the duodenum, $65 \mathrm{mM}$ $\mathrm{NaCl}$ in the jejunum and $18 \mathrm{mM} \mathrm{NaCl}$ in the ileum. The $\mathrm{Cl}$ secretion was maximal for $0 \mathrm{mM} \mathrm{NaCl}, 192 \pm 25 \mu \mathrm{Eq} / \mathrm{h}$ in the duodenum, $115 \pm 15 \mu \mathrm{Eq} / \mathrm{h}$ in the jejunum and $15 \pm 2 \mu \mathrm{Eq} / \mathrm{h}$ in the ileum $\left({ }_{14} F=30.5\right.$, $p<0.001$ ). 

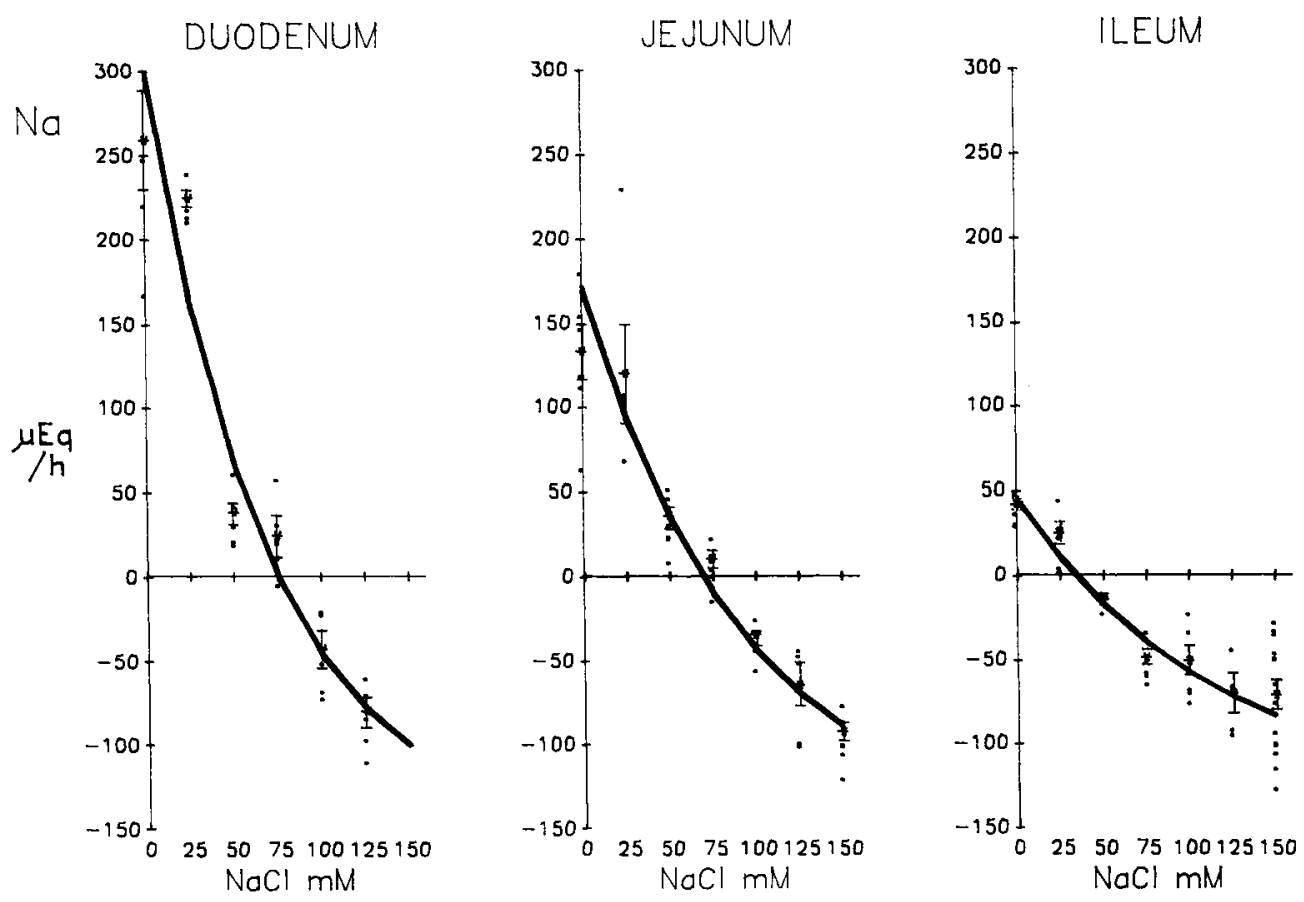

Fig 2. Net sodium flux in the duodenum (left) ( 33 rats), jejunum (middle) ( 43 rats) and ileum (right) (47 rats), according to the initial $\mathrm{NaCl}$ concentration of the test solution (same conditions as in figure 1).

\section{K movement}

Figure 4 shows the individual values, means and non-linear relationship between net $K$ flux and the luminal initial $\mathrm{NaCl}$ concentration. Secretion was observed in all cases. In the duodenum, the $\mathrm{K}$ secretion was low at $125 \mathrm{mM} \mathrm{NaCl}(1.3$ $\pm 0.4 \mathrm{mEq} / \mathrm{h}$ ). Maximal secretion was obtained with the test solution $0 \mathrm{mM} \mathrm{NaCl}$ $(14.4 \pm 2 \mu \mathrm{Eq} / \mathrm{h})$ which differed statistically $\left({ }_{14} F=27.8, p<0.001\right)$ from that obtained in the jejunum $(6.7 \pm 0.7 \mu \mathrm{Eq} / \mathrm{h}, t=5.06)$ and in the ileum $(3.2 \pm 0.2 \mu \mathrm{eq} / \mathrm{h}, t=7.35)$.
Variations in $\mathrm{K}$ flux were of low amplitude in the jejunum and ileum.

\section{Bicarbonate movement}

The difference between the sum of the cations and that of the anions $(\mathrm{Na}+\mathrm{K}-\mathrm{Cl})$ allows the calculation of the other anions which had not been determined such as bicarbonate. The measured bicarbonate, controlled via direct bicarbonate determination, in the duodenum represented $63 \pm$ $3 \%(N=11)$ of the calculated cation-anion 

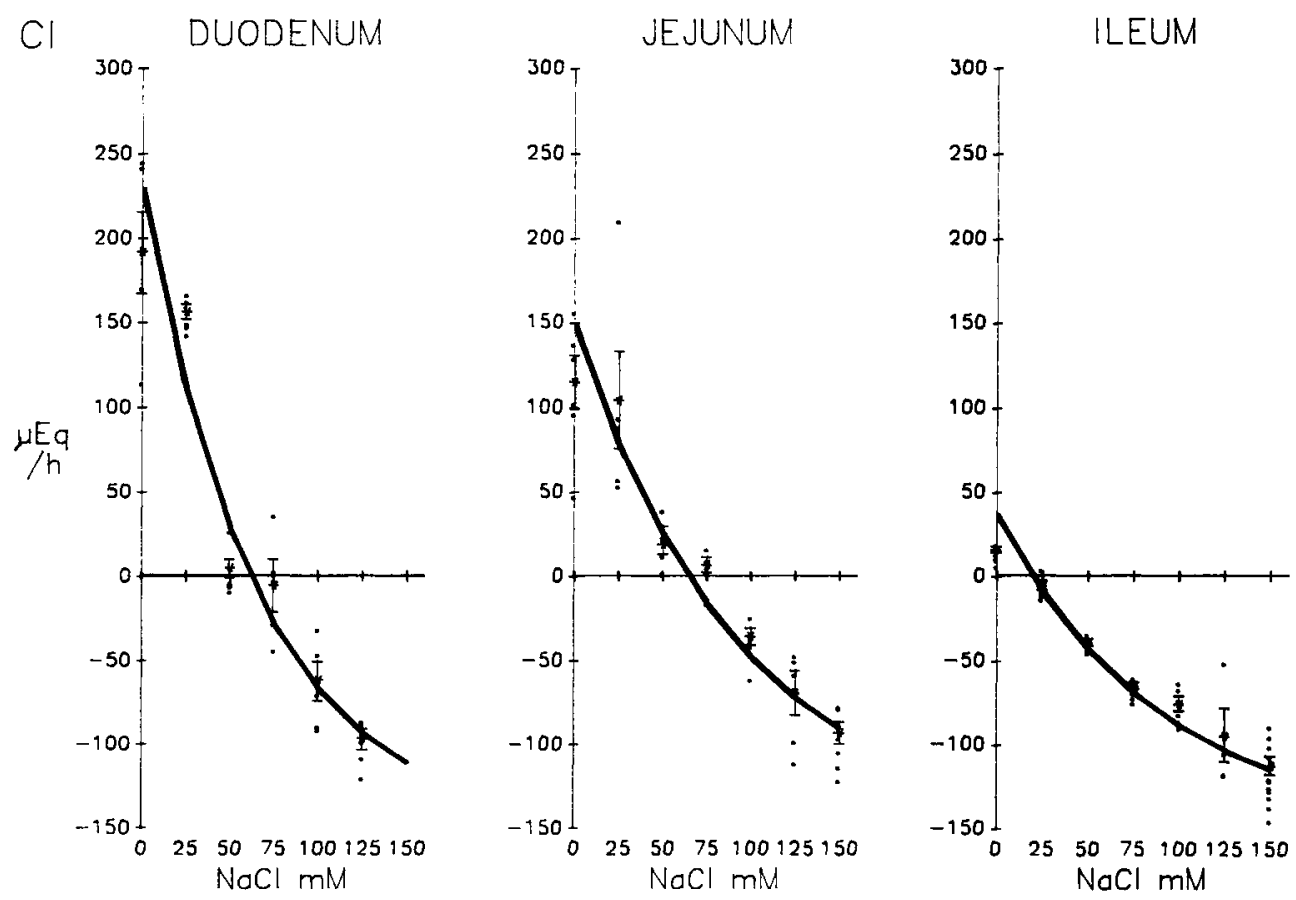

Fig 3. Net chloride flux in the duodenum (left) ( 32 rats), jejunum (middle) (43 rats) and ileum (right) (47 rats), according to the initial $\mathrm{NaCl}$ concentration of the test solution. Same conditions as in figure 1.

difference, in the jejunum $60 \pm 6 \%(N=$ $10)$ and in the ileum $77 \pm 3 \%(N=11)$. Figure 5 shows the individual values, means and nonlinear relationship between bicarbonate (calculated as $\mathrm{Na}+\mathrm{K}-\mathrm{Cl}$ fluxes) and the luminal initial $\mathrm{NaCl}$ concentration. Secretion was present on all the segments. In the duodenum, the secretion was minimal with $125 \mathrm{mM} \mathrm{NaCl}(18 \pm 7$ $\mu \mathrm{Eq} / \mathrm{h})$ and reached $82 \pm 7 \mu \mathrm{Eq} / \mathrm{h}$ with the test solution $0 \mathrm{mM} \mathrm{NaCl}$. In the jejunum, the minimal value was also obtained with $150 \mathrm{mM} \mathrm{NaCl}(2 \pm 2 \mu \mathrm{Eq} / \mathrm{h})$ and the maxi$\mathrm{mal} 25 \pm 2 \mu \mathrm{Eq} / \mathrm{h}$ with the $0 \mathrm{mM} \mathrm{NaCl}$ solution, statistically lower than that obtained in the duodenum but not in the ileum $\left({ }^{2}{ }_{14} F\right.$ $=57.7, p<0.001)$. In the ileum, the secretion $(20-40 \mu \mathrm{Eq} / \mathrm{h})$ did not statistically alter with the $\mathrm{NaCl}$ concentration $\left({ }_{39}^{6} F=1.60\right.$, $p>0.05$ ).

\section{Osmolarity}

An increase in osmolarity was observed in the duodenum and the jejunum when low concentration $\mathrm{NaCl}$ test solutions were instilled whereas the increase was found to be less in the ileum (fig 6). 

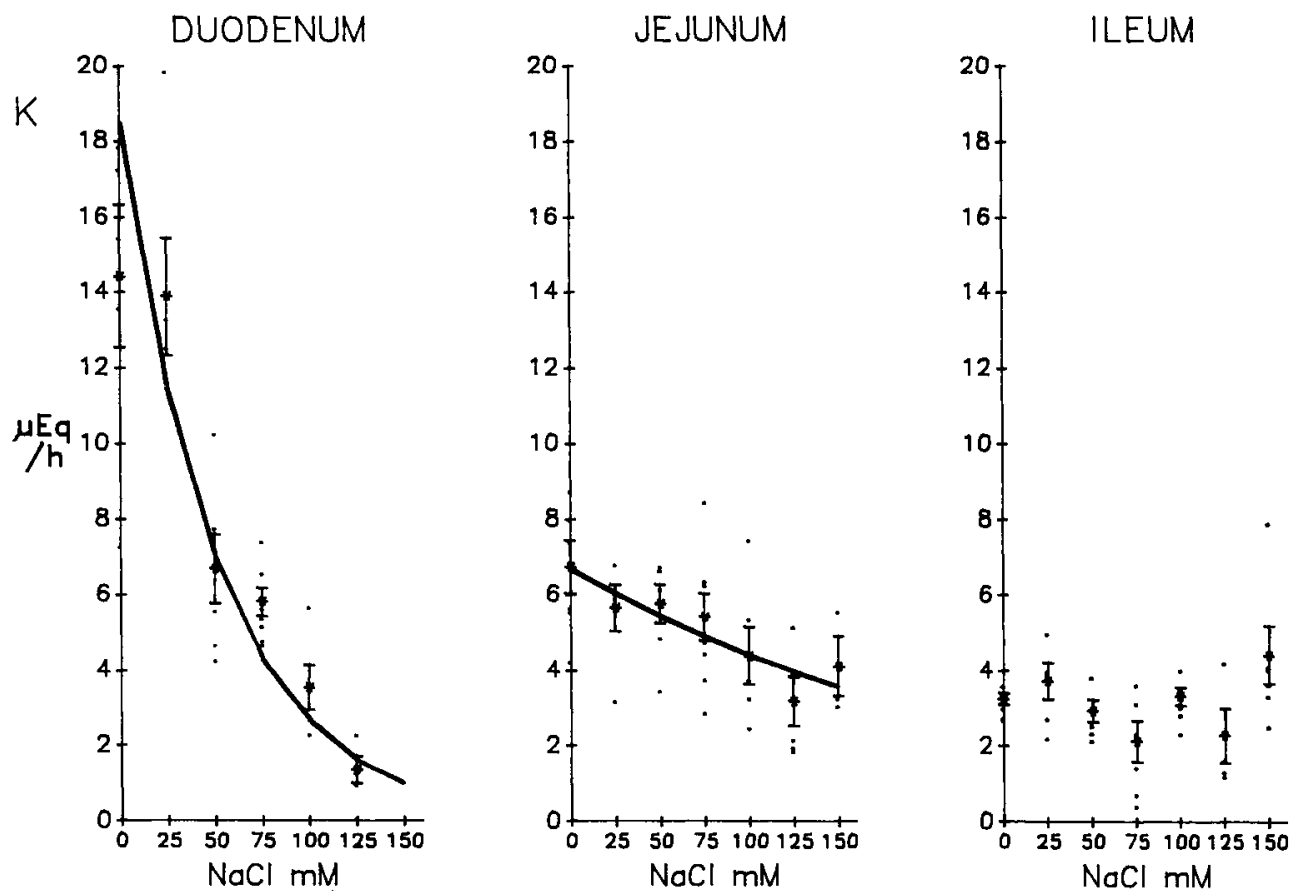

Fig 4. Net potassium flux in the duodenum (left) (32 rats), jejunum (middle) (39 rats) and ileum (right) (40 rats), according to the initial $\mathrm{NaCl}$ concentration of the test solution. Same conditions as in figure 1.

\section{Final concentrations versus initial concentrations}

In the duodenum, the final $\mathrm{Na}$ and $\mathrm{Cl}$ concentrations was diphasic with a minimum value for an initial $\mathrm{NaCl}$ concentration of $50 \mathrm{mM}$ (table I). These concentrations differed significantly from all other values obtained either with lower or higher initial $\mathrm{NaCl}$ concentrations. On the other hand, $\mathrm{K}$ and bicarbonate estimated concentrations were stable. In the jejunum, the final $\mathrm{Na}$ and $\mathrm{Cl}$ concentrations did not differ up to $50 \mathrm{mM} \mathrm{NaCl}$ initial concentration. For $75 \mathrm{mM} \mathrm{NaCl}$, they began to increase statistically and were highest for $150 \mathrm{mM}$ $\mathrm{NaCl}$. Bicarbonate was steady at $\approx 10 \mathrm{mM}$ up. $\mathrm{K}$ concentration increased statistically to become maximal with $150 \mathrm{mM} \mathrm{NaCl}$ test solution. In the ileum, after instillation of the test solution deprived of $\mathrm{NaCl}$, final $\mathrm{Na}$, $\mathrm{Cl}$ and bicarbonate concentrations were significantly lower than in the duodenum and jejunum. Final concentration increased with the increase in initial concentration, while $\mathrm{K}$ concentration was not significantly modified.

\section{Mannitol recovery}

The recovery of mannitol decreased slightly from the duodenum (98\%) to the ileum $(88 \%)$ solution but the variation was not 

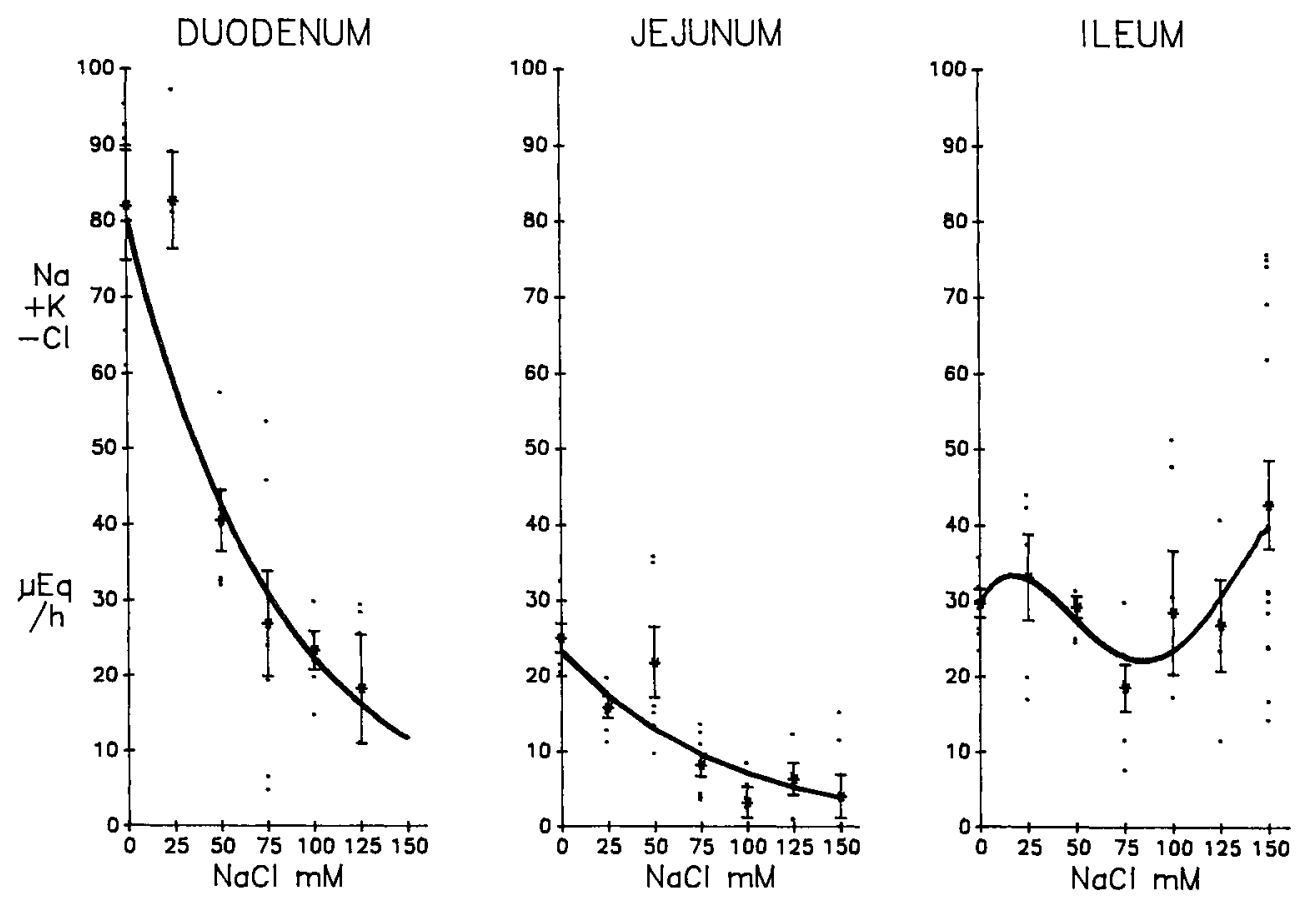

Fig 5. Net bicarbonate flux (calculated as $\mathrm{Na}+\mathrm{K}-\mathrm{Cl}$ ) in the duodenum (left) (32 rats), jejunum (middle) (39 rats) and ileum (right) (40 rats), according to the initial $\mathrm{NaCl}$ concentration of the test solution. Stars indicate the means and vertical bars the SEM. The line represents the exponential curve for duodenum and jejunum. For the ileum, the curve represents the best curve-fitting via non-linear regression which was computerized with Graphpad (ISISoftware; H Motulsky, Dept of Pharmacology, University of California, San Diego, CA, USA). Goodness of fit was quantitated by the least-squares method.

significant. The percentage of recovery was not modified when the mannitol concentration increased in the test solution (table II).

\section{DISCUSSION}

The measurement of intestinal fluxes as a function of the luminal ionic concentration, and at 3 levels of the small intestine allowed the determination of the null transport and the comparison of hourly absorp- tive and secretory capacities of each segment.

When the $\mathrm{NaCl}$ concentration in test solutions varied from zero to $150 \mathrm{mM}$, the response of the intestine varied from an efflux of water and ions for the low ionic test solutions to an influx for high ionic concentrations, as previously shown (Davis et al, 1982; Turnberg et al, 1970a, 1970b). The present study shows that the response can be better described as an exponential decay than as a linear regression. This finding suggests a secretion complementary to 

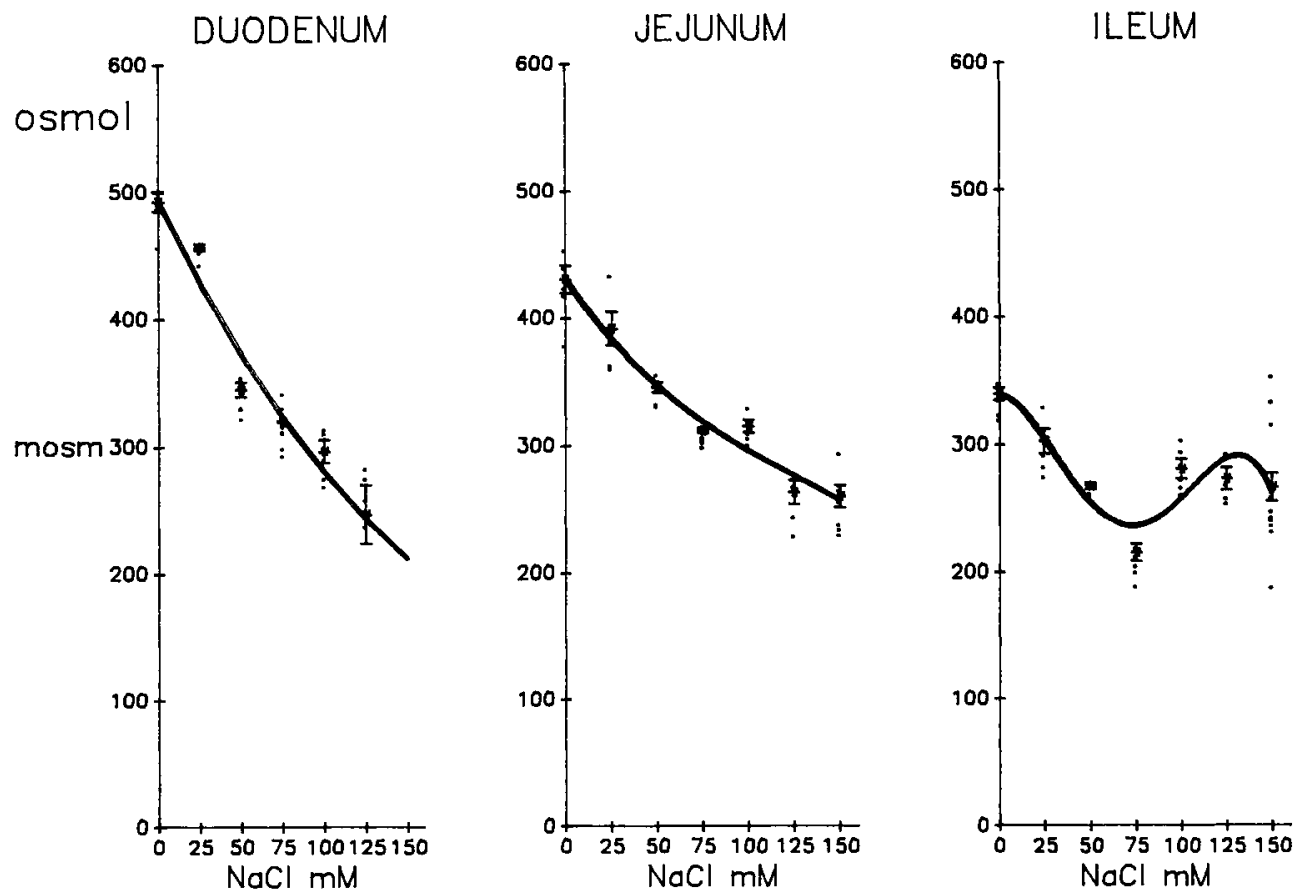

Fig 6. Calculated osmolarity in the duodenum (left) ( 32 rats), jejunum 9 (middle) ( 32 rats) and ileum (right) (40 rats), in function of the initial $\mathrm{NaCl}$ concentration of the test solution. Addition of mannitol provided isoosmolarity $(300 \mathrm{mOsm} / \mathrm{kg})$ in the test solution. Same conditions as in figure 5.

the passive equilibration for the zero $\mathrm{NaCl}$ concentration, and a relative plateauing of the absorption for the $125 \mathrm{mM}$ and $150 \mathrm{mM} \mathrm{NaCl}$ concentrations.

The addition of increasing doses of mannitol did not change its final recovery the proportion entering the intercellular space was independent of net water movement and comparable to the $30-40 \%$ lost during the whole intestinal transit in man, assuming a 3-h transit time (Menzies et al, 1990).

The absence of potassium and bicarbonate in the test solutions led to a secretion at each level even in the presence of water absorption. The final potassium concentration (3.5-6.5 mM) attained the concentration present in the extracellular fluid. The increase for the $150 \mathrm{mM} \mathrm{NaCl}$ test solution in the jejunum and ileum might be secondary to the maximal water absorption. In contrast, the appearance and final concentration of bicarbonate in the lumen varied with the segment and the initial $\mathrm{NaCl}$ concentration. This findings indicates that the distribution between chloride and nonchloride anions depended on the characteristics of the anionic exchangers in the small intestine and on the response of Brunner's glands. 
Table I. Initial (mM) and final concentrations $(\mathrm{mM})$ after $1 \mathrm{~h}$ (means \pm SEM).

\begin{tabular}{|c|c|c|c|c|}
\hline \multirow{2}{*}{$\begin{array}{l}\text { Initial } \\
\mathrm{NaCl}\end{array}$} & \multirow[b]{2}{*}{$\mathrm{Na}$} & \multicolumn{2}{|c|}{ Final } & \multirow[b]{2}{*}{$\mathrm{Na}+\mathrm{K}-\mathrm{Cl}$} \\
\hline & & $\mathrm{Cl}$ & $K$ & \\
\hline \multicolumn{5}{|c|}{ Duodenum } \\
\hline $\begin{array}{l}0 \\
25 \\
50 \\
75 \\
100 \\
125\end{array}$ & $\begin{array}{c}101 \pm 4 \\
109 \pm 4 \\
75 \pm 8 \\
89 \pm 4 \\
102 \pm 5 \\
104 \pm 12\end{array}$ & $\begin{array}{l}74 \pm 5 \\
79 \pm 3 \\
46 \pm 3 \\
62 \pm 7 \\
62 \pm 12 \\
61 \pm 7\end{array}$ & $\begin{array}{l}5.6 \pm 0.6 \\
6.0 \pm 0.5 \\
5.7 \pm 0.8 \\
5.2 \pm 0.4 \\
6.5 \pm 0.6 \\
3.5 \pm 0.9\end{array}$ & $\begin{array}{l}32 \pm 1 \\
36 \pm 2 \\
35 \pm 3 \\
24 \pm 7 \\
47 \pm 8 \\
46 \pm 15\end{array}$ \\
\hline $\begin{array}{l}\text { Variance analysis } \\
F \\
p\end{array}$ & $\begin{array}{l}5_{27} F=5.33 \\
<0.01\end{array}$ & $\begin{array}{l}{ }_{27} F=2.98 \\
<0.05\end{array}$ & $\begin{array}{l}5_{27} F=2.48 \\
>0.05\end{array}$ & $\begin{array}{l}5_{27} F=1.39 \\
>0.05\end{array}$ \\
\hline \multicolumn{5}{|c|}{ Jejunum } \\
\hline $\begin{array}{l}0 \\
25 \\
50 \\
75 \\
100 \\
125 \\
150\end{array}$ & $\begin{array}{r}71 \pm 6 \\
78 \pm 7 \\
75 \pm 2 \\
83 \pm 1 \\
110 \pm 2 \\
114 \pm 6 \\
132 \pm 2\end{array}$ & $\begin{array}{r}61 \pm 6 \\
70 \pm 7 \\
61 \pm 4 \\
78 \pm 1 \\
111 \pm 5 \\
110 \pm 4 \\
130 \pm 6\end{array}$ & $\begin{array}{r}3.6 \pm 0.2 \\
3.7 \pm 0.2 \\
5.1 \pm 0.2 \\
5.1 \pm 0.6 \\
7.6 \pm 1.0 \\
6.5 \pm 0.9 \\
11.0 \pm 1.6\end{array}$ & $\begin{array}{r}14 \pm 1 \\
9 \pm 1 \\
18 \pm 3 \\
8 \pm 1 \\
6 \pm 4 \\
11 \pm 3 \\
10 \pm 7\end{array}$ \\
\hline $\begin{array}{l}\text { Variance analysis } \\
F \\
p\end{array}$ & $\begin{array}{l}{ }_{36} F=40.3 \\
<0.001\end{array}$ & $\begin{array}{l}{ }_{36} F=33.5 \\
<0.001\end{array}$ & $\begin{array}{l}{ }_{32} F=10.1 \\
<0.001\end{array}$ & $\begin{array}{l}{ }_{36} F=1.4 \\
>0.05\end{array}$ \\
\hline \multicolumn{5}{|c|}{ lleum } \\
\hline $\begin{array}{l}0 \\
25 \\
50 \\
75 \\
100 \\
125 \\
150\end{array}$ & $\begin{array}{r}33 \pm 3 \\
40 \pm 5 \\
44 \pm 1 \\
42 \pm 3 \\
96 \pm 5 \\
117 \pm 4 \\
138 \pm 6\end{array}$ & $\begin{array}{l}12 \pm 1 \\
16 \pm 2 \\
13 \pm 2 \\
16 \pm 2 \\
50 \pm 10 \\
56 \pm 20 \\
68 \pm 4\end{array}$ & $\begin{array}{l}2.6 \pm 0.1 \\
3.0 \pm 0.3 \\
3.5 \pm 0.5 \\
3.3 \pm 0.7 \\
7.1 \pm 0.1 \\
4.8 \pm 0.7 \\
9.6 \pm 0.7\end{array}$ & $\begin{array}{l}23 \pm 1 \\
27 \pm 4 \\
35 \pm 2 \\
30 \pm 3 \\
53 \pm 12 \\
66 \pm 16 \\
75 \pm 7\end{array}$ \\
\hline $\begin{array}{l}\text { Variance analysis } \\
F \\
p\end{array}$ & $\begin{array}{l}6{ }_{40} F=66.3 \\
<0.001\end{array}$ & $\begin{array}{l}6{ }_{40} F=15.4 \\
<0.001\end{array}$ & $\begin{array}{l}{ }_{34} F=1.0 \\
>0.05\end{array}$ & $\begin{array}{l}{ }_{40}^{6} F=8.1 \\
<0.001\end{array}$ \\
\hline
\end{tabular}

\section{$\mathrm{NaCl}$ influx}

The maximal $\mathrm{NaCl}$ influx was observed for the $150 \mathrm{mM}$ test solution and decreased from duodenum to jejunum and ileum.
Comparison of ionic influx at the 3 levels must be discussed from the results of the $125 \mathrm{mM} \mathrm{NaCl}$ test solution since absorption was near complete in the duodenum with the highest $\mathrm{NaCl}$ concentration. In the 
Table II. Recovery of $\left[{ }^{14} \mathrm{C}\right]$ mannitol in the contents of the loops after $1 \mathrm{~h}$ as a percentage of the initial content taken as $100 \%$.

\begin{tabular}{rrrrr}
\multirow{2}{*}{$\begin{array}{c}\mathrm{NaCl} \\
(\mathrm{mM})\end{array}$} & $\begin{array}{c}\text { Mannitol } \\
(\mathrm{mM})\end{array}$ & \multicolumn{3}{c}{ Recovery (\%) } \\
\cline { 3 - 5 } & & Duodenum Jejunum & Ileum \\
\hline & & & & \\
75 & 300 & $95 \pm 1$ & $94 \pm 2$ & $88 \pm 3$ \\
125 & 150 & $93 \pm 1$ & $95 \pm 1$ & $84 \pm 8$ \\
& 50 & $90 \pm 5$ & $90 \pm 3$ & $87 \pm 3$ \\
\hline
\end{tabular}

duodenum the influx concentration was $140 \mathrm{mM} / \mathrm{l}$ for $\mathrm{Na}$ and $170 \mathrm{mM} / \mathrm{l}$ for $\mathrm{Cl}$. More $\mathrm{Cl}$ than $\mathrm{Na}$ was absorbed. The difference corresponded to a $\mathrm{HCO}_{3}^{-}$passage into the lumen. This may be secondary to a passive paracellular flux and to a transcellular flux through the double exchange $\mathrm{Cl}^{-}$ $\mathrm{HCO}_{3}^{-}$and $\mathrm{Na}^{+} / \mathrm{H}^{+}$which the first exchange is predominant (Flemström et al, 1982; Hopfer and Liedtke, 1987). The increase of the $\mathrm{pH}$ form $6.8-7.25$ confirmed the exchange of a strong acid against a weak one.

In the jejunum the absorption was lower with an apparent coupled CINa and water absorption occurring without any significant decrease in luminal $\mathrm{pH}$, so the luminal $\mathrm{NaCl}$ concentration did not alter. In the ileum, $\mathrm{Cl}$ absorption was larger than $\mathrm{Na}$ absorption, and associated with a significant increase of $\mathrm{pH}(8.6)$ as described in vivo (Turnberg et al, 1970b) and through the double exchanger $\mathrm{Cl}-/ \mathrm{HCO}_{3}^{-}$. The ileal anionic exchanger, whose function was described on the brush border membrane vesicle system (Knickelbein et al, 1988), is part of the family of band 3 proteins (Alper, 1991); its presence was confirmed by the identification of the gene in rabbit ileum (Chow et al, 1992). At the 3 levels the fluid filling the lumen became slightly hypotonic, the calculated osmolarity being 254 $\mathrm{mOsm} / \mathrm{kg}, 278 \mathrm{mOsm} / \mathrm{kg}$ and $278 \mathrm{mOsm} /$ $\mathrm{kg}$ in the duodenum, jejunum and ileum respectively.

\section{Zero transport}

The zero transport corresponds to the limiting concentration for which absorption changes to secretion; it was found to be $75 \mathrm{mM} \mathrm{NaCl}$ in human ileum, and characterized by the inversion of the potential difference which changed from lumen positive to lumen negative (Davis et al, 1982). In the present experiment, the limiting concentration was higher for the duodenum $(78 \mathrm{mM})$ and jejunum $(70 \mathrm{mM})$ than for the ileum, where the zero $\mathrm{Na}$ transport and the zero $\mathrm{Cl}$ transport were found for a luminal concentration of $41 \mathrm{mM} \mathrm{Na}$ and $18 \mathrm{mM} \mathrm{Cl}$ respectively, values very close to the $27 \mathrm{mM}$ for $\mathrm{Na}$ and $20 \mathrm{mM}$ for $\mathrm{Cl}$ observed in man (Turnberg et al, 1970b).

The zero transport expressed that the lumen to blood flux was equivalent to the blood to lumen flux. As the luminal concentration was lower than the concentration in the extracellular fluid, the absorption had to be principally transcellular. Influx depends on the surface area which decreases aborally on the resistance of the apical membrane and on the number of $\mathrm{Na}^{+} \mathrm{K}^{+}$ pump sites which are sufficient throughout the small intestine (Powell, 1987). The blood to lumen flux depends on the diameter of the pores and on the leakiness of the tight junctions which decrease aborally (Fordtran et al, 1965; Madara, 1991). The decreased lumen to blood permeability explains the increasing capacity of the distal segment to create a chemical gradient. The ration established between the extracellular fluid concentration and the final luminal concentration was $\approx 2$ for $\mathrm{Na}$ and $\mathrm{Cl}$ both in the duodenum and in the jejunum, 
whereas it was 3.5 for $\mathrm{Na}$ and 7.9 for $\mathrm{Cl}$ in the ileum, the highest chloride ratio in ileum being due to the $\mathrm{Cl} /$ bicarbonate exchange and the relative impermeability of the junctions to anions as described in human ileum (Davis et al, 1982).

\section{Zero $\mathrm{NaCl}$ concentration}

Exchange for zero $\mathrm{NaCl}$ concentration provided information about the maximal blood to lumen transport and showed the aboral decrease of the efflux capacity which was $1.54 \mathrm{ml} / \mathrm{h}, 0.84 \mathrm{ml} / \mathrm{h}$ and $0.27 \mathrm{ml} / \mathrm{h}$ in the duodenum, jejunum and ileum respectively. The efflux of sodium was associated with a $\mathrm{Cl}$ and non-chloride secretion, the second was chiefly bicarbonate secretion as evidenced by the good relationship with bicarbonate measurement.

Bicarbonate secretion accounted for one-third of the anionic efflux in the duodenum and for two-thirds of the anionic efflux in the ileum. Several results argue for an active secretion of bicarbonate from Brunner's glands and duodenal enterocytes: 1) the final content in the lumen was made hyperosmolar; 2) the ionic concentration in the efflux was $170 \mathrm{mM} \mathrm{Na}, 124 \mathrm{mM} \mathrm{Cl}$ and $52 \mathrm{mM}$ bicarbonate, ie a concentration higher than the ionic concentration in the extracellular space; 3) the final ionic concentration in the lumen was higher than the minimal concentration which corresponded to the zero flux. This secretion might be secondary to the hormonal and vagal responses to the duodenal distension, or to the synthesis of endogenous prostaglandins (Heylings and Feldman, 1988). In contrast, there was no indication of the activation of a chloride secretory channel in the jejunum: the concentration in the efflux was $157 \mathrm{mM} \mathrm{Na}$ and $134 \mathrm{mM}$ $\mathrm{Cl}$; the passive efflux permitted the concentration corresponding to the zero flux to be established in the lumen. In the same wey the small ionic efflux in the ileum led to a low luminal ionic concentration approximately identical to the one which corresponded to the zero flux. The secretion of ions and particularly the progressive fall in water movement from the proximal to distal segment of the intestine paralleled the secretion described during luminal perfusion of mannitol alone in man (Fordtran et al, 1965). The final osmolarity was 492 $\mathrm{mOsm} / \mathrm{kg}, 430 \mathrm{mOsm} / \mathrm{kg}$ and $339 \mathrm{mOsm} /$ $\mathrm{kg}$ in the 3 segments respectively. In spite of the osmotic activity of mannitol, the lack of ions was particularly and differentialy adjusted by an ionic efflux.

Actually, the exponential analysis showed that the slope of the relationship between $\mathrm{Na}, \mathrm{Cl}$ or water and the luminal ionic concentration was lower in the jejunum than in the duodenum and the lowest in ileum. The differences between the 3 segments appears to be due both to the passive mouvement decreasing with the aboral decrease of the permeability and to a complementary mechanism inducing an active secretion in the duodenum when $\mathrm{NaCl}$ concentration is nil or low. The response of duodenum and ileum to isoosmotic mannitol solutions was described many years ago (Hindle and Code, 1962). Even if the mechanisms were not known the finalist argument that duodenum has to develop and maintain equilibrium with the plasma whereas ileal exchanges are directed to absorption remains sensitive.

Using the ligated loop technique, we have demonstrated the effect of several peptides either stimulating the secretion such as VIP or inducing absorption like D Ala metenkephalinamide, angiotensin II or synthetic peptides derived from natural sorbin. We found that supramaximal doses of the synthetic sorbin-derived peptides decreased the absorptive response (Charpin et al, 1992). The present study suggests that the inhibitory effect of these large dos- 
es of peptides in the duodenum might be related to a secondary electrolyte efflux induced by a decrease in luminal concentration. This apparent limit of the method might be overcome by the use of radioactive ions which can dissociate the net ion flux in ion influx and efflux.

\section{ACKNOWLEDGMENTS}

This work was supported by grant No 2418 from the Programme Régional Rhônes-Alpes de Recherche sur la Mucoviscidose, F-69260 Charbonnières-les-Bains and by grant No 024930008 from Caisse Nationale d'Assurance des Travailleurs Salariés. The authors thank $\mathrm{J}$ Carew for reviewing the English manuscript.

\section{REFERENCES}

Alper SL (1991) The band 3-related anion exchanger (AE) gene family. Ann Rev Physiol $53,549-564$

Armstrong WM (1987) Intestinal water and electrolyte transport. In: Physiology of the Gastrointestinal Tract (Johnson LR, ed) Raven Press New York, 2nd edn, 1251-1265

Charpin G, Chikh-Issa AR, Guignard H, Jourdan G, Dumas C, Pansu D, Descroix-Vagne M (1992) Effect of sorbin on duodenal absorption of water and electrolytes in the rat. Gastroenterology 103, 1568-1573

Chik-Issa AR, Gharzouli A, Charpin G, VagneDescroix M, Pansu D (1992) Comparison of VIP-induced electrolyte secretion at three levels in rat small intestine. Reprod Nutr Dev 32 , 37-45

Chow A, Dobbins JW, Aronson PS, Igarashi P (1992) cDNA cloning and localization of a band 3-related protein from ileum. Am $J$ Physiol (Gastrointest Liver Physiol 26) G345G352

Davis GR, Santa Ana CA, Morawski SG, Fordtran JS (1982) Permeability characteristics of human jejunum, ileum, proximal colon and distal colon: results of potential difference measurements and unidirectional fluxes. Gastroenterology 83, 844-850
Field M (1981) Secretion of electrolytes and water by mammalian small intestine. In: Physiology of the Gastrointestinal Tract (Johnson LR, ed) Raven Press, New York, 2nd edn, 963-982

Flemström G, Garner A, Nylander $O$, Hurst $B C$, Heylings JR (1982) Surface epithelial $\mathrm{HCO}_{3}$ transport by mammalian duodenum in vivo. Am J Physiol (Gastrointest Liver Physiol 6) 243, G348-G358

Fordtran JS, Rector FC, Ewton MF, Soter N, Kinney J (1965) Permeability characteristics of the human small intestine. J Clin Invest 44 , 1935-1944

Heylings JR, Feldman $M$ (1988) Basal and $\mathrm{PGE}_{2}$-stimulated duodenal bicarbonate secretion in the rat in vivo. Am J Physiol 255 (Gastrointest Liver Physiol 18) G470-G475

Hindle W, Code CF (1962) Some differences between duodenal and ileal sorption. Am J Physiol 203, 215-220

Hopfer U, Liedtke CM (1987) Proton and bicarbonate transport mechanisms in the intestine. Ann Rev Physiol 49, 51-67

Knickelbein RG, Aronson PS, Dobbins JW (1988) Membrane distribution of sodiumhydrogen and chloride-bicarbonate in crypt and villus cell membranes from rabbit ileum. J Clin Invest 82, 2158-2163

Madara JL (1991) Functional morphology of the small intestine. In: Handbook of Physiology Section 6. The Gastrointestinal System. Intestinal Absorption and Secretion (Schultz SC, ed) Am Physiol Soc, Bethesda, MD, 83120

Menzies IS, Jenkins AP, Heduan E, Catt SD, Segal MB, Creamer B (1990) The effect of poorly absorbed solute on intestinal absorption. Scand J Gastroentero/25, 1257-1264

Powell DW (1987) Intestinal water and electroIyte transport. In: Physiology of the Gastrointestinal Tract (Johnson LR, ed) Raven Press, New York, 2nd edn, 1267-1305

Turnberg LA, Fordtran JS, Carter NW, Rector FC (1970a) Mechanism of bicarbonate absorption and its relationship to sodium transport in the human jejunum. $J$ Clin Invest 49 , 548-556

Turnberg LA, Bieberford FA, Morawski SG, Fordtran JS (1970b) Interrelationships of chloride, bicarbonate, sodium and hydrogen 
transport in the human ileum. $J$ Clin Invest $49,557-567$

Vagne-Descroix $M$, Pansu $D$, Jörnvall $H$, Carlquist $M$, Guignard $H$, Jourdan $H$, Desvigne A, Collinet M, Caillet C, Mutt V (1991) Isola- tion and characterization of porcine sorbin. Eur J Biochem 201, 53-59

Weast RC ed (1986-1987) Handbook of Chemistry and Physics 67. CRC, Boca Raton, D237-D-253 